\title{
Representation Women Subordinated of Java Culture in Bumi Manusia by Pramudya Ananta Toer
}

\author{
Mukti Widayati ${ }^{1}$, Farida Nugrahani ${ }^{2}$, Titik Sudiatmi ${ }^{3}$, Benedictus Sudiyana ${ }^{4}$, Joko \\ Suryono 5 \\ 1,2,3,4,5 Veteran Bangun Nusantara University, Sukoharjo, Indonesia \\ muktiwidayati65@gmail.com
}

\begin{abstract}
The purpose of this research is to reveal gender inequity forms of subordination experienced by female characters in the novel Bumi Manusia by Pramoedya Ananta Toer. This study uses a qualitative approach. The research data are words, phrases, sentences, paragraphs and in the form of a collection of paragraphs that contain forms of gender subordinate inequity. The data source in this study is a document in the form of the novel Bumi Manusia by Pramoedya Ananta Toer. The data collection techniques use library techniques, reading techniques, and note taking techniques. The data analysis techniques use dialectical techniques and content analysis techniques. The results of the study concluded that the form of gender subordination in the novel Bumi Manusia was a belief that one sex was considered more important or more primary than the other sex.
\end{abstract}

Keywords: Subordination; Culture; Gender Inequity.

\section{INTRODUCTION}

Subordination is the placement of a particular person or group as an inferior or additional class. Who exactly is the one who reports this subordination culture. Men have a big role in creating women's subordination, especially in Javanese society. The view that places women as a lower class or an additional class in Javanese culture is very thick whatsoever for the priyayi classes. The view of men who subordinate women is reflected in the expressions of kanca wingking. This expression is often represented in literary works. Placing women as very important objects. In a number of literary works it is represented differently according to the views of the author. Javanese local literary works cannot be separated from this. For example the works of Ahmat Tohari, Linur Suryadi, Umar Khayam, and Arswendo Atmowiloti. From Srintil, Pariyem, Sri Sumarah, until Bu Bei were figures who were used by the author to represent subordination in the Javanese view. These figures were placed as they should have been Javanese women. It seems different from the view of Darmanto Jatman in the poem "Isteri". The author places women as not just marginalized objects, but the Javanese people's views actually regard women as the kanca wingking who are right in accordance with their nature. It is this placement that is in accordance with its nature that is considered by men as glorifying women. In the poem, it was revealed that the woman was important to men and their families. The authors of Javanese local colors are mostly men who place themselves as others. The novels position women closer to the affairs of the kitchen, wells, mattresses. The role of the kanca wingking shows a very important thing, as a tetimbangan not just doing domestic work. Women have the right to decide matters related to expressing widely in Indonesian literature. 
Pramudya Ananta Toer, the author of Blora (Java), represents many subordinated views of women in some of his novels. Bumi Manusia is one of the novels that represents the role of women subordinated by men.

A novel is a literary work of a story, which tells of an extraordinary event from the lives of people (characters). It was said to be an extraordinary event because of this incident a conflict arose, which diverted the fate of the figures. According to Hardjana[1] the novel is processing social problems by educated Indonesians since the 1920s and is very popular with writers.

Social, cultural, and literary facts become an inevitable part of their role in expressing women's lives. How the role of women is strongly related to the social and cultural community as stated by Robert Linton[2] that someone who has a certain role can behave according to the person imaginary works that represent social true and cultural facts. Therefore, literature is often a reflection of its social and cultural reality. This is causes society and literature to become an inseparable part. In other words, literature has a dialectical relationship between the two. Literary work is a social fact or reflection of life in society. The creation of literary works always comes from phenomena that occur in society, literary works reveal social structures, functions and roles of each member of the community and the interactions within them.

The issue of women has become a matter of much discussion in Indonesian literature. Among them regarding gender refraction, existence, oppression, and women's struggle. One of them is a problem that reveals the depiction or social criticism of women oppressed by patriarchal culture. In these conditions women are subordinated so that they have a relatively low function, role, and position which are stereotypically low[3]. Women and their problems that continue to occur throughout this age are most easily found in literary works, one of which is in the form of novels that focus on women.

Feminism is a women's movement that demands full equality of rights between women and men which departs from an awareness of oppression and extortion of women in society in the political, economic and social fields[4]. The construction of the culture of Javanese gender inequity places women as beingsinferiorcan result in the emergence of forms of gender inequity that occur against women not only reflected in real life but the phenomenon also described in literature, namely novels.

The system of gender inequity that occurred, resulted in the emergence of the ruling class, nobility, bourgeoisie, aristocrats, and lower classes consisting of laborers, farmers and servants. Such a system makes the lower class society, be it farmers, laborers, and so on, must submit and respect the ruling class. The women in the novel before the war were described as objects, obedient, weak, defeated, helpless against the forces of discriminatory and feudal cultural systems so that women were defeated by cultural establishment and dragged down by forced marriage (to pay their parents' debts)[5]. By the community, this is considered very reasonable because women do not play much role in carrying out policies that exist in the family and society.

The study of feminist literature is expected to be able to find subordinate problems contained in the novel Bumi Manusia by Pramudya Ananta Toer. This study focused its attention on the subject of women in their status as individual authors and readers[2]. Feminist literary studies will answer 1) How a literary text represents women, 2) Defines femininity and masculinity, 3) Asks, criticizes, and confirms the situation, status and position of participation in society.

\section{MATERIALS AND METHODS}

This study uses a qualitative descriptive method. According to Kencana[6], qualitative research methodology is a human curiosity towards something new pushed by the supreme gift of the Creator to humans, namely mind. 
The data collection techniques used were library techniques, reading techniques, note taking techniques. Library techniques are techniques that use written sources to obtain data[2]. It is done by reading comprehension and getting data about novel conversations or quotes from Bumi Manusia then read and recorded according to the data in the novel.

Data analysis techniques carried out are dialectical techniques and content analysis techniques. The dialectical technique is part of the genetic structuralism theory approach. The basic principle of the dialectical method that makes it related to the problem of coherence above is his knowledge of the facts of humanity which will remain abstract if it is not made concrete by integrating it into the whole. In this connection, the dialectical method develops two pairs of concepts, namely the whole and Goldmann's understandings[3]. Content analysisis a research technique for making inferences are replicable and valid data of context[6]. This analysis is often used in text research with the basic assumption that text is a means of communication.

The validity of the data in this study was carried out through source triangulation. Triangulation in the form of resources means comparing and checking both the degree of trust in information obtained through time and different tools in qualitative research Patton[7].

\section{RESULT AND DISCUSSION}

Subordination is an assessment or assumption that a role performed by one sex is lower than another. In this case the subordination of women is an assumption that the role of women is lower than that of men.

Nyai Ontosoroh experienced subordination or was considered low position by Mr. Mellema. His position as concubine ( $g$ undik), Ontosoroh is considered low position and is even considered a puppet that can be played and used for pleasure only by men. Women at that time were considered not to have roles like men. Women are seen as low and weak. In fact, women do not have a role in society or even their country, women at that time did not even have a stake in regulating the right to life and themselves. All of them are regulated and governed by men, while women only obey without being able to fight.

Ontosoroh's subordination also occurs in education. As a indigenous, Ontosoroh is not entitled to have education like a Dutch woman. Indigenous roles especially women at that time were considered not necessary to get an education because the assumption that the woman did not need to be smart was because the task of women was only at home serving her husband. Women at that time were considered unable to replace the role of men, so women could not get education which made them weak and uneducated women so that they were easily enslaved by those who felt more educated than them. Gender biases experienced by women leaders put them in a neglected position, women at that time always got inequitys in the economic, social, and educational fields because of the assumption that their parents only needed help at home. Besides Nyai Ontosoroh, there were other figures who experienced subordinate acts, namely Maiko, Sie-sie, Min Hwa and other women. Subordination of women who described the degrading attitude of women experienced by Maiko, Sie-sie, Min Hwa, and women who were made sex workers by Ah Tjong. Subordinate act to women in their homes to satisfy the passions of the guests who come to visit. The coordination of women is evident because men only consider the role of women as satisfying appetites and merely giving pleasure, the women depicted in the quote are only used as satisfying passions of the guests as well as looking down on a woman. At that time the role of Indigenous women was greatly underestimated or deemed useless, especially women like Maiko, Sie-sie, Min Hwa who in fact was just a prostitute. This makes these women considered not to have a role other than just satisfying the passions of men. 
Subordination to the other Nyai Ontosoroh, subordination to women by assuming that women are goods that can be traded. Sanikem or Nyai Ontosoroh were sold as concubines, in this case the father who could sell Nyai Ontosoroh for the sake of office. This shows how a person who is deemed not to have a role as a woman so that he easily underestimated his existence, lowered his self-esteem, and also claimed the rights to himself. Life at that time was commonly found by a woman exploited for the benefit of people who felt a higher degree. The quotation above shows that the female character Nyai Ontosoroh is placed in a position that is considered insignificant and is only considered a subordinate of men.

Sanikem or Nyai Ontosoroh who have experienced acts of gender inequity which in this case are subordinated since she was a child. The thirteen-year-old began to cringe (pingit), and only knew the kitchen in the back room and her own room. Sanikem loses rights and freedoms as women. When she was thirteen years old he had to be cringe (pingit) and she only knew the kitchen, back room and her own room(dapur, ruang belakang dan kamarnya sendiri). Indeed the role of women is ruled out by men at that time, they assume that women are only weak creatures so they assume that women do not need to get a high education, because according to men women are only in charge of serving their husbands later. At that time it was true that women were limited to "konco wingking", as many Javanese proverbs say that women could only get dressed, childbirth, and cook (macak, manak, masak). As low as that was the assumption of men towards women at that time.

The mother of Nyai Ontosoroh also experienced subordination. The role of women who are underestimated by men, let alone to have a role in big things. Their rights and roles to submit opinions are not needed by men, so at that time women are only be bent down to orders and opinions of men. It was clearly subordinated to Indigenous women of the time, their right to voice their opinions was considered something that was taboo and not even important. Subordination acts as if they had become entrenched in society at that time. The process of inequity experienced by women has many happened and become entrenched in society at that time. Women at that time were not entitled to determine their own lives, did not even have the right to choose their own partners. Women must obey what is determined by their parents, not a few women who don't even know their future husbands at all. Women must serve men for the rest of their lives, but on the other hand men are free to treat women. Its happens because women's marriages are determined by their parents, some are sold for various purposes, such as paying off debts, gambling, positions and so on. Subordination is clearly seen because the role of women seems to be turned off by parties who feel they have a higher degree.

Nyai Ontosoroh, who is in fact a concubine (gundik), often experiences subordination or is considered to be an insignificant role as a woman, the destiny as a Nyai puts her often down graded because only a slave whose job is only to serve her master in any case. It is clear that the position of women is very low compared to men, where many women are made as prostitutes and gratification of masculine men, even though a woman also has self-esteem, has the right to live without being a slave to the natural desire of a man.

Representasi demikian itu tidak lepas dari filosofi perempuan Jawa. Sikap narimo merupakan ekspresi kehidupan yang religius, bahwa perempuan menerima kodrat alam, taat pada leluhur. Hal tersebut sesuai dengan perumusan bahwa 1) religiusitas orang Jawa sangat tinggi, mereka percaya dan berlindung kepada Tuhan; 2) orang Jawa meyakini bahwa manusia adalah bagian dari kodrat alam; 3) orang Jawa menjadikan memayu hayuning bawana. Based on Achmadi in[8] that memayu hayuning bawana makes the basic of the Javanese view of life, so culture has placed women in accordance with their roles to maintain a balanced life. Ontosoroh's sincerity is a form of life balance. 


\section{CONCLUSION}

Subordination of women/girls in the Bumi Manusia needs to be taken into account in the development of Indonesian literature. Although the views of Javanese culture are subordinated as the placement of women who are appropriate or even glorifying, the imaginary reality of subordination actually places women in a low position. Women are not given their rights as human beings. Gender subordination in women is a belief that one sex is considered more important or more primary than the other sex.

\section{REFERENCES}

[1] A. I. Al-Ma'ruf, Dimensi Sosial Keagamaan dalam Fiksi Indonesia Modern. Solo: Smart Media, 2010.

[2] Risnawati, "Peran Ganda Istri yang Bekerja dalam Membantu Ekonomi Keluarga Buruh Perkebunan Kelapa Sawit pada PT. Bumi Mas Agro di Kecamatan Sandaran Kabupaten Kutai Timur," e-journal Sosiatri dan Sosiol., vol. 4, no. 3, pp. 84-97, 2016.

[3] Faruk, Pengantar Sosiologi Sastra: Dari Strukturalisme Genetik sampai PostModernisme. Yogyakarta: Pustaka Pelajar, 2012.

[4] D. Y. C. Wahono, S. N. Haryati, and S. S. Sumartini, "Pengaruh Kekuasaan Laki-laki Terhadap Perempuan dalam Novel The Chronicle of Kartini Karya Wiwidd Prasetyo Kajian Feminisme," J. Sastra Indones., vol. 4, no. 1, 2015.

[5] M. Widayati, Wanita dulu, Kini, dan Masa Datang dalam Sastra Indonesia. Bahasa dan Sastra Indonesia Menuju Transformasi Sosial Budaya Abad XXI. Yogyakarta: Gama Media, 2002.

[6] B. Bungin, Penelitian Kualitatif. Jakarta: Kencana Prenada Media Group, 2008.

[7] Sutopo, Metodologi Penelitian Kualitatif. Surakarta: Sebelas Maret University Press, 2002.

[8] H. P.R., "Human and Javanese Culture in the Romance of Bumi Manusia," J. Aksara, vol. 27, no. 1, 2015. 